\title{
Urgensi Tasawuf di Tengah Pandemi Covid
}

\author{
Siti Rahmah \\ UIN Antasari Banjarmasin \\ Email: sitirahmah@uin-antasari.ac.id
}

\begin{abstract}
The spread of Covid-19 continues to develop rapidly and widely, which greatly affects human social life in various aspects, one of which is human behavior. Ofcourse this is not a simple problem of the Corona virus outbreak testing all capacities as humans by facing uncertainty, even though it is believed that Allah Swt must certainly create disease and of course the cure.

Every human being will experience problems in his life, including when he is going through difficult, anxious and pessimistic times as well as depression as a result of the Covid-19 pandemic. The problem is whether every human being is able to survive these problems. In the perspective of Sufism, the problems of life are very much influenced by the form of acceptance and interpretation of the events experienced, when a person is not able to properly understand the meaning of life's trials and is unable to accept Allah's provisions for His creatures, life's problems will be even heavier. For those who are aware and have knowledge, will try to solve it either independently or by asking for help from an expert. One of the alternatives to solve life's problems is by doing tasawuf. How a Muslim responds to the Covid-19 outbreak there are at least three things that a Muslim's needs to do in facing tests like this, namely sincerity, patience, and gratitude.
\end{abstract}




\section{ABSTRAK}

Penyebaran Covid-19 terus berkembang pesat dan luas, yang sangat mempengaruhi kehidupan sosial manusia dalam berbagai aspek, salah satunya adalah perilaku manusia. Tentunya ini bukan persoalan sederhana wabah virus Corona yang menguji seluruh kemampuan sebagai manusia dengan menghadapi ketidakpastian, padahal diyakini Allah Swt pasti menciptakan penyakit dan tentunya obatnya.

Setiap manusia pasti akan mengalami masalah dalam hidupnya, termasuk saat ia sedang mengalami masa-masa sulit, cemas dan pesimis serta depresi akibat pandemi Covid-19. Masalahnya adalah apakah setiap manusia mampu bertahan dari masalah ini. Dalam perspektif tasawuf, permasalahan kehidupan sangat dipengaruhi oleh bentuk penerimaan dan tafsir atas peristiwa yang dialami, ketika seseorang tidak mampu memahami dengan baik makna cobaan hidup dan tidak dapat menerima ketentuan Allah bagi makhluk-Nya. , masalah hidup akan semakin berat. Bagi yang sadar dan memiliki ilmu, akan berusaha menyelesaikannya baik secara mandiri maupun dengan meminta bantuan dari ahlinya. Salah satu alternatif untuk mengatasi masalah kehidupan adalah dengan melakukan tasawuf. Bagaimana seorang muslim menyikapi wabah Covid-19 setidaknya ada tiga hal yang perlu dilakukan seorang muslim dalam menghadapi ujian seperti ini, yaitu keikhlasan, kesabaran, dan syukur.

KATA KUNCI: Pandemi Covid-19, Sufisme, Ketulusan, Kesabaran, Syukur

\section{Pendahuluan}

Coronavirus 2019 (Covid-19) adalah penyakit menular yang disebabkan oleh sindrom pernapasan akut coronavirus 2 (Sars-CoV-2). Pada bulan Desember 2019 penyakit ini ditemukan di Wuhan Ibukota Provinsi Hubei China untuk pertama kalinya, dan semenjak itulah menyebar mendunia sehingga berdampak pada pandemi corona virus 2019-2020. Organisasi Kesehatan Dunia (WHO) mendeklarasikan wabah koronavirus 2019-2020 sebagai Kesehatan Masyarakat Darurat Internasional (PHEIC) pada 30 Januari 2020, dan pandemi pada 11 Maret 2020, hampir 200 Negara di dunia terjangkit oleh virus corona ini termasuk Negara Republik Indonesia, karenanya wabah penyakit ini sangat mengguncang masyarakat dunia. (https://en.wikipedia.org/wiki/Coronavirus_disease_2019).

Covid-19 adalah varians dari virus-virus yang pernah melanda di dunia seperti SARS, flu burung, Flu babi, dan MERS. Namun yang membedakan adalah 
mudah menular, transparansi informasi, kekurangan pasokan bagi tenaga medis, masalah inkubasi virus tidak jelas, karantina berskala besar, dan "infodemic" yang unik, yaitu banyaknya informasi di media sosial yang menyebabkan pengaruh psikologis pada banyak orang (Dong \& Bouey, 2020). Dalam hitungan hari dan bulan saja, virus ini sudah menyebar ke seluruh negara di dunia, bahkan di Indonesia, hampir semua provinsi telah terdeteksi kasus COVID-19. Selain itu, dampak COVID -19 ini begitu dashyat dampaknya sampai kehilangan nyawa atau kematian, penurunan dan pelambatan ekonomi (resesi), terganggu aktivitas pendidikan, ekonomi dan sosial, dan yang paling mengkhawatir berpengaruh pada mental/psikologis yang pada akhirnya mengakibatkan perubahan perilaku pada masyarakat.

Ketika bersinggungan dengan situasi pandemi seseorang akan merasakan diantaranya perasaan khawatir, cemas maupun stres adalah sesuatu hal yang biasa, karena ini merupakan bentuk mekanisme pertahanan diri atau tanda bahwa ada ancaman yang di hadapi. Namun, apabila berlebihan, maka akan menganggu kondisi psikologis seseorang, seperti mengalami depresi. Kondisi tersebut sebenarnya secara umum saat ini masih berada dalam tataran normal, karena yang sangat perlu dikhawatirkan adalah akibat dari pandemic COVID-19 sendiri seperti ekonomi. Kenapa demikian? Karena ekonomi akan berhubungan dengan pekerjaan dan kebutuhan hidup seseorang. Dilihat dari data Kementerian ketenagakerjaan bahwa sampai tanggal 10 Apri 2020, sekitar 1,5 juta yang kehilangan pekerjaan karena COVID-19 (CNBNIndonesia, 2020). Dengan kehilangan pekerjaan tersebut otomatis kebutuhan hidup akan terganggu, maka kondisi ini akan rentan mengakibatkan gangguan mental/psikologis lebih berat dibandingkan dengan COVID-19 itu sendiri. Dengan demikian pandemi COVID19 secara tidak langsung mempengaruhi kondisi mental/psikologis.

Tulisan ini bermaksud memberikan jawaban bagaimana pendekatan tasawuf dalam menghadapi masa pandemi sekarang ini baik orang-orang yang tidak terpapar maupun yang terpapar Covid-19, karena disaat seseorang dihadapkan suatu masalah, sebagai solusi diantaranya ada 3 hal yang seharusnya dilakukan, pertama adalah bersabar. Dengan bersabar mengajarkan seseorang untuk lebih tenang mengahadapi masalah yang dialami dalam kehidupan saat ini. Kendatipun sebagian orang beranggapan bahwa sabar merupakan sesuatu 
hal yang sangat sulit untuk dilakukan, tetapi ketika dilakukan dengan ikhlas maka hal itu dapat membawa ketenangan pada hati dan pikiran (jiwa).

\section{Pembahasan}

\section{Tasawuf di Masa Pandemi Covid 19}

Pandemi Covid-19 merupakan salah satu ujian atau cobaan dari Allah Swt. untuk menguji para hambanya bagaimana menyikapi adanya ketentuan takdir yang telah ditentukan sebagaimana firman Allah Swt:

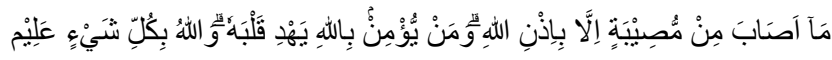

Artinya: "tidak ada musibah yang menimpa seseorang kecuali dengan izin Allah dan barangsiapa yang beriman kepada Allah Subhanahu wa Ta'ala, Allah akan memberi petunjuk kepada hatinya" (QS. At-Thaghabun: 11)

Dari ayat tersebut tergambar sangat jelas bahwa tidak ada seorang hamba ditimpa suatu musibah kecuali apa yang Allah Swt telah tuliskan kepadanya, karenanhya seorang hamba dalam kondisi seperti ini sangat perlu untuk selalu memperbaharui keimanannya dan memperbaharui keyakinan terhadap takdir Allah Swt. bahwa apa yang dikehendaki pasti akan terjadi dan apa yang Allah tidak diinginkan pasti tidak akan terjadi.

Manusia sebagai makhluk yang beragama tentu memiliki rasa keagamaan dan kemampuan untuk memahami serta mengamalkan nilai-nilai agama, dan kefitrahannyalah yang membedakan manusia dengan hewan sehingga mengangkat harga dirinya dihadapan Allah Swt. dan sebagai makhluk yang memiliki kesadaran, manusia menyadari adanya persoalan dalam kehidupan yang mengganggu sebagai ujian. Karena secara alamiah manusia menghendaki kehidupan yang tenang dan sehat, baik secara lahiriyah maupun bathiniyah, karena kesehatan tidak hanya berkaitan dalam hal jasmaninya saja tetapi juga akan terkait dengan kesehatan mental

Pada dasarnya ajaran dalam agama Islam meliputi tiga hal, yaitu akidah (keyakinan), ibadah (perbuatan), dan akhlak (keadaan jiwa). Ajaran Akidah adalah ajaran yang membahas tentang keyakinan atau keimanan kepada Allah Swt dan rukun-rukun iman lainnya. Ajaran Ibadah adalah ajaran yang membahas tentang pengabdian diri kepada Allah Swt. dan ajaran akhlak adalah ajaran yang membahas tentang keadaan jiwa dan pengaruhnyanya dalam perilaku seseorang muslim. Ilmu yang membahas ajaran akidah disebut ilmu tauhid atau ilmu kalam, 
ilmu yang memahas ajaran ibadah disebut ilmu fiqih, dan ilmu yang membahas ajaran akhlak disebut ilmu akhlak atau ilmu tasawuf.

Sebagai orang yang beriman, seseorang semestinya meyakini bahwa, wabah covid-19 tersebut adalah sebuah bentuk ujian yang harus di hadapi sebagai mana Firman Allah Swt:

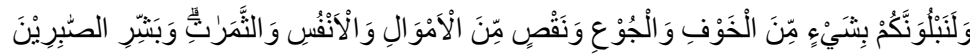

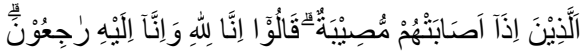

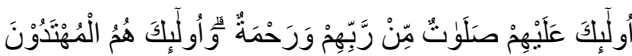

Artinya: "Dan sungguh akan kami berikan cobaan kepadamu, dengan sedikit ketakutan, kelaparan, kekurangan harta, jiwa dan buah-buahan. Dan berikanlah berita gembira kepada orang-orang yang sabar. (Yaitu) orang-orang yang apabila ditimpa musibah, mereka mengucapkan: "Inna lillaahi wa innaa ilaihi raaji'un" (segala sesuatu milik Allah dan kembali kepada Allah). Mereka itulah yang mendapat keberkatan yang sempurna dan rahmat dari Tuhan mereka dan mereka itulah orang-orang yang mendapat petunjuk." (QA: Al-Baqarah:155-157)

Wabah Covid-19 saat ini adalah ujian dan cobaan yang akan menambah kekuatan apabila seseorang dapat mengambil hikmahnya, karena sebuah ujian dan cobaan yang data dari Allah Swt bukanlah untuk melemahkan, tetapi justru sebaliknya merupakan alat untuk menambah kekuatan bagi iman seseorang yang mungkin sudah mulai melemah, dan kalau dihubungkan dengan wabah Virus Corona-19 sudah jelas tidak akan terlepas dari ajaran akidah dan tasawuf bahwa segala bentuk bencana yang terjadi kepada manusia dipermukaan bumi ini dan apapun bentuknya yang mengakibatkan munculnya perasaan khawatir dan takut dalam hati yang di sebabkan suatu ujian musibah dari Allah Swt. Untuk itu Tasawuf menawarkan ajaran batin atau esoteris dalam mengisi dimensi ruhani manusia menjadi hal yang utama dalam memahami dan merasakan hidup yang sesungguhnya.

Menjalani kehidupan dengan jalan tasawuf berarti mendekatkan diri kepada Allah Swt. dengan melaksanakan perintah-perintah Allah Swt. dan menjauhi semua larangan-larangan-Nya berdasarkan syari'ah dan akal untuk berada sedekat mungkin dengan Allah Swt. dan memperoleh akhlak mulia sehingga mendapatkan sebuah kebahagiaan dunia maupun akhirat. Menjalani kehidupan bertasawuf tentu memiliki sumber, metode, tahapan-tahapan dan teknik-teknik. (Bustomi \& Setiawan, 2020:8) Bagaimana seorang Muslim dalam menyikapi 
wabah Corona? Ada tiga hal yang perlu dilakukan oleh seorang Muslim dalam menghadapi ujian seperti ini, yakni sabar, ikhlas dan syukur.

\section{Sabar}

Sabar secara etimologi berasal dari bahasa arab, yaitu șabara-yasbiru-sabran yang artinya menahan. Kata lainnya adalah alhabs yang artinya menahan atau memenjarakan. Artinya adalah menahan hatinya dari keinginan atau nafsunya. Sedangkan menurut istilah sabar dalam Kamus Besar Bahasa Indonesia adalah tahan menghadapi cobaan, tidak cepat marah, putus asa atau patah hati. (Abu Sahlan: 2010: 2)

para ahli memberikan pengertian sabar dengan berbagai macam pengertian, sebagaimana misalnya yang diungkapkan oleh Al-Maraghi, sabar adalah ketabahan hati dalam menanggung berbagai macam kesulitan sebagai upaya mencegah perbuatan-perbuatan yang tidak disenangi dan dalam rangka melaksanakan ibadah, serta ketabahan dalam menjauhi perbuatan-perbuatan maksiat. (Ahmad Musthafa Al-Maraghi; 1992; 10)

Menurut Ibnu Qayyim al-Jauziyyah, sabar artinya menahan diri dari rasa gelisah, cemas dan amarah; menahan lidah dari keluh kesah; menahan anggota tubuh dari kekacauan. Menurut Achmad Mubarok, pengertian sabar adalah disaat seseorang ingin mencapai sebuah tujuan dalam jangka waktu tertentu seseorang tabah hatinya dan tidak mengeluh ketika berhadapan dengan godaan dan rintangan apapun. Menurut Muhammad Rabbi Muhammad Jauhari bahwa para ulama menyebutkan sejumlah definisi tentang sabar, di antaranya:

a. Sabar adalah ketika seseorang meminum sesuatu yang pahit dengan wajah manis.

b. Mampu bertahan dalam menghadapi musibah,

C. Istiqamah atas aturan-aturan Al-Quran dan As-Sunnah,

d. Tidak berkeluh kesah

e. Tidak ada perbedaan antara sedang nikmat dan sedang diuji meskipun duaduanya mengandung bahaya (Muhammad Rabbi Muhammad Jauhari; 2006; 342)

Sabar dalam tradisi tasawuf adalah salah satu diantara maqam yang mesti ditempuh oleh para sufi. Maqom adalah tingkatan dimana seseorang telah 
dianugerahi oleh Allah menuju tingkat yang lebih tinggi lagi, dimana seseorang tersebut harus berusaha menjalankan perintah Allah dan sabar dalam menjauhkan diri dari larangan-larangan-Nya, dan menerima segala sesuatu yang telah ditentukan oleh Allah Swt kepadanya. (Abu Baiquni \& Arni Fauziana: 1995: 128)

Imam al-Ghazali mengemukakan pendapatnya tentang sabar yaitu suatu tingkatan di antara berbagai tingkatan agama dan sabar merupakan tahapan di antara berbagai tahapan orang-orang yang menjalankan suluk (menuju pada jalan Allah), dan semua tingkatan dalam agama itu tersusun dalam tiga hal yaitu: Pertama, IImu/ma'rifat/pengetahuan, Kedua Keadaan/ahwal, dan ketiga Amal/perbuatan. IImu didiskripsikan sebagai pohon, keadaan sebagai cabang dan amal ibarat buahnya. Oleh karena itulah, tidak akan sempurna sabar seseorang kecuali dengan ma'rifat yang mendasarinya dan dengan hal ihwal yang tegak berdiri. ( Imam Abu Hamid al-Ghazali: 1985: 73), selanjutnya Imam alGhazali lebih jauh menjelaskan bahwa sabar merupakan gambaran kokohnya dorongan agama seseorang dalam menghadapi syahwat dan dorongan agama seseorang dalam menaklukkan syahwat lalu menentangnya, maka ia telah menolong pasukan Allah Subhaanahu Wa Ta'ala dan dikategorikan sebagai orang yang penyabar dan jika dorongan agamanya kalah, lemah, dan dapat dikuasai oleh syahwat serta tidak mampu menolaknya, maka ia dikategorikan sebagai pengikut setan. (Jamaluddin Al-Qasimiy: 1975: 902)

Menurut Al-Ghazali sabar adalah jika dipandang sebagai pengekangan tuntutan nafsu dan amarah, dinamakan sebagai kesabaran jiwa (ash-shabr annafs), sedangkan menahan terhadap penyakit fisik, disebut sebagai sabar badani (ash-shabr al-badani). Kesabaran jiwa sangat dibutuhkan dalam berbagai aspek. Misalnya, untuk menahan nafsu makan dan seks yang berlebihan. (Rosibon Anwar: 2004: 72)

Al-Ghazali menjadikan sabar sebagai satu keistemewaan dan spesifikasi makhluk manusia. Sikap mental tersebut tidak dimiliki oleh binatang, juga para malaikat. Al-Ghazali membedakan sabar kepada tiga tingkatan, yaitu: 1) sabar untuk senantiasa teguh (istiqamah) dalam melaksanakan perintah Allah swt., 2) sabar dalam menghindarkan dan menjauhkan diri dari perbuatan-perbuatan yang dilarang oleh Allah Swt, 3) sabar dalam menghadapi atau menanggung 
cobaan dari Allah Swt. (M. Alfatih Suryadilaga: 102) karenanya dapat ditegaskan bahwa sabar adalah seseorang yang mampu menerima semua ujian ataupun cobaan yang di berikan oleh Allah Swt dengan tabah, menahan diri dari sifat marah, menahan diri dari berkeluh kesah, menahan lisan dari mengadu, mampu menghadapi musibah dan menjaga anggota badan agar tidak terjadi hal-hal yang negatif.

Dengan demikian sabar dapat dijadikan sebagai sarana penyembuhan yang ampuh pada saat menghadapi ujian berupa sakit, karena dengan mengembalikannnya kepada Allah Swt dan sabar terhadap segala keputusanNya tentu akan mampu membuat seseorang dapat menahan segala serangan rasa sakit yang dialaminya, bahkan lebih jauh rasa sakit tersebut akan menjadi sebuah jalan untuk lebih mendekatkan diri kepada Allah Swt dan memahami betapa besar kekuasaan-Nya.

Sabar merupakan sebuah upaya pengendalian diri ketika mengalami kesulitan dengan cara tidak mengeluh, tidak gelisah, tidak merasa susah dan berlaku tenang, karena sabar merupakan sebuah upaya seorang manusia sebagai hamba Allah Swt dalam mengendalikan dirinya disaat mengalami kesusahan hidup sehingga membuatnya termasuk orang sabar yang dapat menggapai keridhaan Allah Swt

Dalam Islam sifat sabar dipandang sebagai salah satu sifat terpuji yang harus dimiliki oleh orang-orang yang beriman kepada Allah SWT. Orang yang tidak sabar tidak bisa dikatakan sebagai orang yang beriman. Sesuai pandangan Islam, diantaranya macam sabar adalah: Pertama, Sabar dalam melaksanakan segala perintah Allah Swt, yaitu menahan diri agar tetap istiqamah dalam menjalankan apa yang diperintahkan oleh Allah Swt, karena Allah Swt telah menjanjikan surga bagi hamba-Nya yang melaksanakan perintah-Nya dengan baik sesuai syariat yang telah Allah SWT turunkan. Diawali dari shalat, zakat, puasa, dakwah, dan lainlain itu semua harus dijalani dengan sabar. Kedua Sabar terhadap apa yang dilarang Allah Swt. yakni sebagai umat Islam tentunya harus bersabar terhadap semua yang dilarang oleh Allah Swt. meyakini bahwa semua dilarang pasti ada maksudnya. Tidaklah Allah Swt melarang hambanya untuk berbuat dosa, kecuali dalam dosa itu pasti terdapat sebuah kerugian yang akan didapat bila melakukannya. Dan ketiga, Sabar terhadap apa yang telah ditakdirkan Allah Swt. 
bahwa ujian di saat sekarang ini menghadapi pandemi Covid-19 ini memang benar-benar memerlukan kesabaran. Seseorang dituntut untuk bersabar dan berdiam diri di rumah, keluar rumah apabila hanya untuk kondisi darurat, karenanya ditengah wabah Covid-19 sekarang ini dengan sabar menjaga jarak, sabar menjauhi kerumuman dan sabar untuk tidak mudik dapat dijadikan sebagai sarana memantapkan kesabaran. Sifat sabar dalam pandangan Islam harus dimiliki oleh orang-orang yang beriman kepada Allah Swt sebagai salah satu sifat yang terpuji.

Pada saat sekarang ini semua cobaan atau ujian yang dialami, baik yang berupa kekurangan bahan makanan, kehilangan harta, kehilangan jiwa dari saudara yang tercinta, atau kehilangan tempat tinggal, termasuk wabah Covid-19 ini. Semua jauh lebih ringan daripada cobaan yang dialami oleh salafush shalih dan para ulama di masa lalu. Mereka disakiti, dimusuhi, didustakan, dituduh yang bukan-bukan, bahkan ada juga yang dikucilkan. Ada yang mengalami kemiskinan harta, bahkan ada juga yang sampai meninggal di dalam penjara, tetapi mereka sama sekali tidak membuat runtuh sendi keimanan mereka.

Sabar merupakan salah satu teknik dalam bertasawuf, sabar di sini adalah berusaha meneguhkan jiwa dalam menghadapi segala sesuatu yang memberatkannya dalam bertasawuf termasuk wabah penyakit Covid-19. (Bustomi \& Setiawan, 2020:75).

Sabar bukanlah sesuatu yang harus diterima seadanya bahkan sabar merupakan suatu usaha yang harus dilakukan dengan sungguh-sungguh yang juga merupakan sifat Allah Swt yang sangat mulia dan tinggi, lebih jauh dikatakan bahwa sabar adalah menahan diri dalam menanggung sebuah penderitaan, baik dalam sesuatu persoalan yang tidak diinginkan maupun dalam hal kehilangan sesuatu yang disukai. (M. Khatib Quzwain: 90)

Dengan demikian sabar merupakan kekuatan batin yang mampu menjadikan seseorang tabah dalam menghadapi segala ujian sehingga seseorang mampu menguasai dan memimpin dirinya secara baik, (M. Yatimin Abdullah: 2007: 41) Karena seseorang yang memiliki kesabaran selalu yakin dan optimis bahwa penderitaan yang berkepanjangan, yang seakan tidak berkesudahan, pasti akan ada akhirnya. Setelah itu, ia yakin akan munculnya kemuliaan dan kejayaan, dan sabar bukanlah sebuah sikap menerima apa adanya 
terhadap segala sesuatu yang menimpa, tetapi justru sabar sebagai sumber kekuatan untuk menuju kehidupan yang lebih baik, karena sabar merupakan sebuah sikap kejiwaan yang dapat memberikan pengaruh positif sebagai pengendalian diri terhadap berbagai tekanan di dalam kehidupan manusia.

\section{Ikhlas}

Menurut bahasa ikhlas diartikan dengan bersih, suci. Sedangkan menurut terminologi, ikhlas berarti sebagai niat yang murni semata-mata mengharap penerimaan dari Allah Swt dalam melaksanakan sebuah perbuatan, dengan tidak menyekutukan Allah Swt dengan yang lain (Qalami, 2003). Sedangkan secara kontekstual, ikhlas berarti beramal dengan tidak menyekutukan Allah Swt dengan yang lainnya, memurnikan niatnya dari kotoran yang merusak niat tersebut dengan hanya mengharap ridha Allah Swt semata. (www.dakwatuna.com, 2008).

Menurut Imam al-Qusyairi dalam kitab Risalatul Qusyairiyahnya (1990: 183) bahwa pengertian ikhlas berarti bermaksud menjadikan Allah SWT, sebagai satusatunya sesembahan. Dan menurut Hamka (1983: 95) dalam bukunya Tasawuf Modern menjelaskan bahwa pengertian Ikhlas adalah ikhlas artinya bersih, tidak ada campuran, ibarat emas; emas tulen, tidak ada campuran perak berapa persenpun. Pekerjaan yang bersih terhadap sesuatu itu dinamakan ikhlas.

Ikhlas adalah melakukan segala amal perbuatan baik lahir maupun batin hanya ditunjukkan kepada Allah. Dan tidak mengharapkan sesuatu pun melainkan kepada Allah dan karena Allah. Tidak menginginkan pujian dan penghargaan dari orang lain dan tidak merasa bangga dengan amalannya apabila diketahui oleh orang lain. Dia tidak pernah merasa gembira dan tenang apabila mendapa pujian orang. Akan tetapi apabila dipuji orang, segera ia memuji Allah, karena Allah telah memberinya taufiq dengan menunjukkan kebaikannya sehingga terlihat oleh banyak orang. (Mohammad Toriquddin: 2008: 87)

Ikhlas merupakan salah satu akhlak yang mulia, dan setiap muslim diharapkan dapat melaksanakannya dalam beramal dan beribadah. Amalan sebagai jasadnya dalam beragama, sedangkan keikhlasan sebagai roh bagi manusia dalam beragama. Jasad tanpa roh tak akan ada artinya seperti seonggok mayat yang terbujur kaku tiada harganya, demikian juga dengan amal ibadah 
tanpa adanya keikhlasan adalah satu hal yang sia-sia tidak berguna, seperti melukis di atas permukaan air yang tidak akan ada membekas.

Ikhlas sebenarnya sangat luas dan mencakup segala amal ibadah yang dilakukan manusia dengan dibarengi perasaan tulus di dalam hati. Sebagai contoh, seseorang yang melakukan pengabdian atau memberikan sesuatu kepada orang lain tanpa mengharapkan imbalan apapun kecuali keridhaan Allah semata-mata, maka sikap tersebut dapat dinamakan ikhlas.

Ikhlas pada hakikatnya adalah "niat, sikap, atau perasaan yang timbul dalam hati nurani yang dalam pada diri seseorang dandisertai dengan amal perbuatan". Ikhlas juga dapat dimaknai sebagai "ketulusan dalam mengabdikan diri kepada tuhan dengan segenap hati, pikiran dan jiwa seseorang". (Cyrill Glasse: 1999: 62). Dalam hal ini Muhammad al-Ghazali mengatakan bahwa ikhlas yaitu "melakukan suatu amal semata-mata karena Allah, yakni semata-mata karena iman kepada Allah Swt". (Mohd. al-Ghazali: t.th: 139)

Oleh karena itulah dapat dipahami bahwa ikhlas adalah mengerjakan segala sesuatu yang telah digariskan oleh Allah dan Rasul-Nya (ibadah) dengan penuh ketulusan semata-mata hanya untuk mendapat keridhaan-Nya, baik di dunia maupun diakhirat. Ikhlas merupakan kunci amalan hati. Semua amalan shalih tidak akan sempurnatanpa dilandasi keikhlasan kepada Allah SWT semata. Bahkan makan, minum ataupun berolah raga, juga harus didasari keikhlasan.

Pada ajaran sufi keikhlasan adalah suatu yang diperlukan untuk mendekatkan diri kepada Allah sama ada dari sudut niat maupun tindakan. (M. Khatib Quzwain: 1985: 16) Jadi ikhlas merupakan sesuatu hal yang bersifat batiniyah dan teruji kemurniannya dengan amalan saleh, ia merupakan perasaan halus yang tidak dapat diketahui oleh siapapun. Amal perbuatan adalah bentukbentuk lahiriyah yang boleh dilihat sedangkan roh amal perbuatan itu adalah rahasia yaitu keikhlasan. (M. Khatib Quzwain: 1985: 19)

Dalam kitab Minhajul Abidin, Imam al-Ghazali menuturkan bahwa: "Dan Ikhlaslah kamu dengan ikhlas yang sebenar-benarnya" maksudnya mampulah untuk ikhlas taat kepada Allah yang sebenar-benarnya (al-Ghazali, terj. Masyruh, $57: \mathrm{tt})$.

Imam al-Ghazali menekankan bahwa keikhlasan yang dilakukan seorang hamba haruslah ikhlas yang nyata. Bukan hanya ikhlas yang dalam perkataannya 
saja. Misal: "Aku ikhlas beribadah kepada Allah" namun pada kenyataan dalam hatinya masih mengharapkan pujian orang lain, masih merasa kesal karena beribadah. Sesungguhnya bukanlah hal tersebut ikhlas yang nyata. Ikhlas yang nyata diwujudkan dengan beribadah yang istiqomah, berusaha dengan sepenuh hati untuk taat kepada Allah. taat dengan keikhlasan yang sebenarnya karena mencintai Allah dan mengagungkan-Nya.

Keikhlasan bukanlah hal yang statis, yang sekali terwujud akan senantiasa bertahan selamanya didalam diri manusia, tetapi ikhlas sesuatu yang dinamis yang senantiasa menuntut kesungguhan pemeliharaan dan peningkatan karenanya keikhlasan adalah Langkah bagi manusia untuk menumbuhkembangkan potensinya untuk memberikan kesan pada amalan atau perbuatan dan teruji dalam kualitas maupun kuantitas (Nurcholish Madjid: 1992: 50)

Ikhlas merupakan sesuatu hal yang sangat mudah untuk diucapkan namun sangat sulit untuk dilaksanakan. Ikhlas mempunyai posisi yang sangat urgen dalam setiap amal perbuatan yang dilakukan manusia, karena tanpa keikhlasan, semua perbuatan baik sebesar apapun tidak akan diridhai oleh Allah swt. Seyogianya setiap perbuatan seharusnya dilakukan dengan ikhlas kendatipun sangat berat tetapi tetap dijadikan sebagai dasar agar perbuatan tersebut diterima Allah Swt.

Disaat ini semuanya harus menyatukan Langkah untuk melawan covid-19 dengan langkah-langkah yang tepat dan sesuai dengan anjuran pemerintah, karenanya harus berjuang secara nyata untuk memerangi pandemic covid-19, yang seyogianya dihadapi dengan sabar dalam setiap cobaan, karena dengan kesabaran akan tumbuh keikhlasan, dan keikhlasan merupakan satu hal yang sangat penting untuk menyempurnakan ibadah kepada Allah Swt.

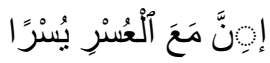

Artinya: Sesungguhnya bersama kesulitan itu ada kemudahan. (QS. AlInsyirah: 6)

Sebagai seorang hamba sudah seharusnya ikhlas atas segala ketentuan dan kehendak Allah, karena apapun yang terjadi tentu tidak lepas dari kehendak Allah Swt, Termasuk terjadinya wabah pandemic Covid-19 yang saat ini sedang 
melanda negeri ini. menjadi ladang ibadah yang memberikan peluang kepada seseorang untuk ikhlas berbuat baik seluas-luasnya.

\section{Syukur}

Shukr atau bersyukur berarti berterima kasih. Sering dikatakan "ayo bersyukur" atau "bersyukurlah" dalam menjalani kehidupan keseharian, maksudnya berterima kasih pada semua nikmat atau pemberian. Makna syukur tersebut sangat indah, disamping mengenal pemberi nikmat, juga mengakui terhadap nilai yang melekat pada syukur itu sendiri. Syukur dapat diterapkan baik bentuk lisan maupun dalam qalbu, syukur bentuk lisan dipraktikkan berupa pengakuan terhadap anugrah yang diberikan Allah Swt dalam bentuk keridhaan, sedangkan syukur dengan qalbu yakni ketenangan dan kedamaian yang diraih dengan melakukan perbuatan terpuji secara kontinu. (Tamami HAG: 2011: 202)

Secara etimologi syukur bahasa berasal dari kata "syakara" yang berarti membuka, sebagai lawan dari kata kafara (kufur) yang berarti menutup. (Abdul Halim Fathani: 2008: 734)

Al-Qusyairi mengatakan, "hakikat" syukur adalah pengakuan terhadap nikmat yang telah diberikan Allah yang di buktikan dengan ketundukan kepadaNya. Jadi, syukur itu adalah mempergunakan nikmat Allah menurut kehendak Allah sebagai pemberi nikmat. Karena itu, dapat dikatakan bahwa syukur yang sebenarnya adalah mengungkapkan pujian kepada Allah dengan lisan, mengakui dengan hati akan nikmat Allah, dan mempergunakan nikmat itu sesuai dengan kehendak Allah. (Komaruddin Hidayat: 2009: 38)

Menurut Imam Al-Ghazali syukur adalah menggunakan nikmat-nikmat yang diperoleh pada hal-hal yang disukai Allah Swt. Dan ketika seseorang tidak menggunakan nikmat pada hal yang disukaiNya, melainkan sebaliknya maka itu dikatakan sebagai orang yang kufur nikmat (Al-Ghazali, 2007:360). Memahami hal-hal yang dicintai Allah, perlu memahami bahwa Allah adalah yang menciptakan segala sesuatu di dunia ini, dalam bentuk apapun itu baik suka maupun duka, baik sekecil atau sebesar apapun, semuanya mengandung hikmah, dan hikmah itu pasti ada maksud, dan apabila mampu memahami maksud tersebut dengan baik, maka itulah yang dicintaiNya (Shobihah, 2014: 390). 
Bersyukur tidak hanya dalam bentuk zikir lisan, tetapi juga dalam bentuk perbuatan atau aksi nyata. (Amir An-Najar: 2001: 251) Karena itulah mari besarkan jiwa sosial kita untuk membantu saudara-saudara kita yang terdampak aturan Work From Home yaitu bekerja dari rumah atau bekerja di rumah dan physical distancing atau jaga jarak aman untuk memutus penularan Covid-19. Memberikan bantuan untuk mereka yang membutuhkan, baik secara individual maupun berjamaah dengan kelompok warga, kantor, teman dan lain-lain.

Bersyukur masih diberi nikmat kesehatan, masih mendapatkan gaji kendatipun kerja di rumah, masih dapat rezeki dari berbagai jalan yang Allah Swt siapkan. Sementara, sebagian saudara-saudara kita seperti kalangan menengah bawah, kemungkinan masih banyak mereka yang menghadapi kesulitan keuangan akibat adanya wabah Covid-19. Seperti tukang ojek, pedagang asongan, dan lain-lain.

Syekh Abdul Qadir al-Jailani mengatakan bahwa hakikat syukur adalah mengakui nikmat Allah karena Dialah pemilik karunia dan pemberian sehingga hati mengakui bahwa segala nikmat berasal dari Allah Swt. Kemudian anggota badannya tunduk kepada pemberi nikmat itu. Yang disebut tunduk adalah mentaati dan patuh karena seseorang tidak disebut tunduk, kecuali jika dia mentaati perintah Allah dan patuh kepada syari'at-Nya. Dengan demikian syukur merupakan pekerjaan hati dan anggota badan. Syekh Abdul Qadir al-Jailani menjelaskan tentang cara bersyukur sebagai berikut, bersyukur dengan lisan adalah lisan mengakui bahwa nikmat itu berasal dari Allah dan tidak menyandarkannya kepada makhluk atau kepada dirimu sendiri, daya mu, kekuatanmu, atau usahamu. Syukur dengan hati adalah dengan keyakinan yang abadi, kuat, dan kokoh bahwa semua nikmat, manfaat, dan kelezatan yang ada padamu, baik lahir maupun batin, gerakanmu maupun diammu adalah berasal dari Allah bukan dari selain-Nya, dan kesyukuranmu dengan lisanmu merupakan ungkapan dari apa yang ada di dalam hatimu. Sedangkan bersyukur dengan anggota badan adalah hendaknya kamu menggerakkan dan menggunakannya untuk ketaatan kepada Allah bukan untuk selainnya dari makhluk. (Sa'id bin Musfir al-Qahthani: 2003: 502-503)

Menurut pandangan Psikologi, rasa syukurmerupakan gambaran psikologis internal individu yang positif yang terbukti secara signifikan dalam diri seseorang 
dapat memunculkan perasaan bahagia, tenang, dan damai bagaimanapun kondisi yang dihadapinya. Dan perasaan bahagia, tenang, dan damai tersebut, dalam perspektif medis, dapat meningkatkan imunitas tubuh sehingga tubuh lebih kuat dalam merespons dan melawan penyakit.

Di tengah kehidupan yang baru disaat wabah covid-19 sekarang, maka rasa syukur ini dapat menjadi benteng pertama yang dibangun oleh individu dalam menghadapi virus yang tak terlihat. Lantas bagaimana memunculkan rasa syukur sehingga terwujudnya hamba yang syakuur, hamba yang dapat melihat kebaikan-kebaikan Allah walaupun dalam keadaan sulit?

Didalam cobaan wabah pandemi covid 19 sekarang ini sudah pasti ada hikmah yang sangat besar yang Allah Swt berikan dan tunjukkan kepada manusia, seperti misalnya salah satu hikmah yang semua orang rasakan yaitu semakin dekatnya keakraban di dalam keluarga, contohnya bisa shalat berjamaah Bersama keluarga di rumah, tadarus Al-quran bersama-sama, dan tentunya banyak Jagi kegiatan-kegiatan lainnya di rumah sebagai hikmah dari ujian dan wabah pandemi covid-19 yang sudah dirasakan dalam keluarga.

Dengan demikian di antara cara yang dapat ditempuh untuk menjadi hamba yang bersyukur dalam keadaan sulit adalah dengan berusaha dan meningkatkan husnuzhon, berbaik sangka kepada Allah Swt. dengan meyakini bahwa Allah memiliki sifat Maha Pengasih lagi Maha Penyayang, meyakini bahwa semua terjadi atas izin kuasa Allah dan tidak akan membebani hamba-hamba-Nya lebih dari kemampuan mereka, meyakini bahwa semua terjadi atas izin Allah dan segala kejadian pasti ada hikmah kebaikan di dalamnya.

\section{Simpulan}

Wabah atau musibah virus Covid-19 menjadi ujian yang sangat luar biasa bagi umat Islam di berbagai belahan dunia. Hal tersebut diperuntukkan Allah Swt untuk mendesain dan menata keimanan, meningkatkan ketakwaan hamba-Nya bahwa ada kekuasaan mutlak di dunia ini.

Perjuangan dan pengorbanan dalam melawan pandemi corona virus disease -19 (Copid-19) belum jelas sampai kapan, sampai saat ini belum ada yang dapat memprediksi secara tepat kapan pandemi ini akan berakhir, dan untuk 
menghadapi kondisi tersebut tasawuf memberikan jalan yakni dengan bersabar, karena dengan bersabar akan memberikan pelajaran kepadanya untuk lebih tenang ketika mengahadapi masalah seperti pada masa pandemi ini. Kendatupun sebagian orang menganggap bahwa sabar merupakan sesuatu hal sulit untuk dilakukan, tetapi ketika melakukannya dengan ikhlas pasti akan membawa ketenangan pada hati dan pikiran (jiwa), dan ketika seseorang mendapatkan ketenangan tentu akan dapat bersyukur sehingga kehidupan ini akan menjadi lebih baik dan bermakna, karena segala sesuatu yang datangnya dari Allah pasti membawa suatu pesan bagi umat manusia.

Mari bersama-sama menyikapi wabah Covid-19 ini dengan baik dan waspada agar terhindar dari wabah tersebut, karena sudah seharusnya selalu waspada dan menjaga diri seraya mendekatkan dirikepada Allah Swt dan janganlah menyikapinya dengan sepele.uk mengisi garapan dakwah yang semakin luas dan beragam, terutama dengan pemanfaatan teknologi informasi yang semakin cepat di era disrupsi secara efisien, maksimal dan efektif. Wallahu'alam bi alshawab.

\section{Referensi}

Abdullah, M. Yatimin. 2007. Studi Akhlak dalam Perspektif A/-Qur'an.Jakarta: Amzah.

Al-Ghazali, Imam Abu Hamid. 1985., Ihya' 'Ulum al-Din, terj. Ismail Ya'kub, dengan judul Ihya' Al-Ghazali, J akarta: Faizan, cet. II, jil. VI.

Al-Ghazali, Muhammad. 1986. Akhlak Seorang Muslim, terj. Mohd. Rifa'i. Semarang: Wicaksana.

Al-Maraghi, Ahmad Musthafa. 1992. TafsirAl-Maraghi, terj. Bahran Abu Bakar, dkk. Semarang: Toha Putra.

Al-Qahthani, Sa'id bin Musfir. 2003. Buku Putih Syaikh Abdul Qadir alJailani. Jakarta: PT Darul Falah

Al-Qasimiy, Jamaluddin. 1975. Mauidhat al-Mukminin min Ihya' Ulum al-Din, Juz 1. terj. Moh. Rathami. Bandung: Diponegoro.

An-Najar, Amir. 2001. Ilmu Jiwa dalam Tasawwuf, Studi Komparatif dengan IImu Jiwa Kontemporer. Jakarta: Pustaka Azzam.

Anwar, Rosihan dan Mukhtar Solihin. 2004. Ilmu Tasawuf. Bandung: Pustaka Setia. Baiquni, Abu \& Arni Fauziana. 1995. Kamus Istilah Agama Islam. Surabaya: Arkola. 
Bustomi, J., Setiawan, C. 2020. Ilmu Akhlak Menyingkap Misteri Tasawuf Menoreh Akhlak Karimah. Bandung: Fakultas Tarbiyah dan Keguruan Universitas Islam Negeri Sunan Gunung Djati.

Dong L, \& Bouey J .2020. Public Mental Health Crisis During COVID-19 pandemic, China. Emerging Infection Diseases. 7, 23-26 https://doi.org/10.3201/eid2607.200407

Fathani, Abdul Halim. 2008. Ensiklopedi Hikmah (Memetik Buah Kehidupan Di Kebun Hikma). Jogyakarta: Ar-Ruzz Media.

Glasse, Cyrill. 1999. Ensiklopedi Islam Ringkas (the Consice Encyclopaedia of Islam), terj. GhufronA. Mas' adi, Jakarta: Raja Grafindo Persada.

Hag, Tamami. 2011. Psikologi Tasawuf. Bandung: Pustaka Setia Hidayat, Komaruddin. 2009. Dahsyatnya Syukur, Jakarta: Qultum Media. Jauhari , Muhammad Rabbi Muhammad. 2006. Keistimewaan Akhlak Islami, terj. Dadang Sobar. Jakarta: Pustaka Setia.

Madjid, Nurcholish. 1992. Islam Doktrin dan Peradaban. Jakarta: Pustaka Paramadina.

Mustofa, A. 199. Akhlak Tasawuf. Bandung: Pustaka Setia.

Nata, Abuddin. 2002. Akhlak Tasawuf. Jakarta: PT RajaGrafindo Persada.

Qalami, A. F. 2003. Ringkasan Ihya' Ulumiddin. Surabaya: Gitamedia Press.

Quzwain, M. Khatib. 1985. Mengenal Allah: Suatu Pengajian Mengenai Ajaran

Tasawuf Syaikh Abdul Samad Al-Palimbani. J akarta: Pustaka Bulan Bintang.

Selamat, Kasmuri dan Ihsan Sanusi. 2012. Akhlak Tasawuf, Upaya Meraih Kehalusan Budi dan Kedekatan Ilahi, J akarta: Kalam Mulia.

Solihin, M. dan Rosihan Anwar. 2008. IImu Tasawuf. Bandung: Pustaka Setia.

Suryadilaga, M. Alfatih. 2016. Ilmu Tasawuf. Yogyakarta: Kalimedia.

Toriquddin , Mohammad. 2008. Sekularitas Tasawuf. Malang: UIN-Malang Press. www.dakwatuna.com.

https://en.wikipedia.org/wiki/Coronavirus_disease_2019 